Review Paper

\title{
Digital human modeling (DHM) for improving work environment for specially-abled and elderly
}

\author{
Charu M. Maurya ${ }^{1}$ [D Sougata Karmakar ${ }^{1} \cdot$ Amarendra Kumar Das $^{1}$
}

(c) Springer Nature Switzerland AG 2019

\begin{abstract}
Digital human modeling (DHM), a technique of simulating human interaction with the product or workplace in a virtual environment is gaining popularity. This virtual evaluation process is useful in developing user-centered products by incorporating human factor principles at an early design phase, which reduces the design time and improves quality. Application of DHM has gained attention in the design process of the manufacturing industry, agriculture, healthcare sectors, transportation and aviation sectors, etc. However, the use of DHM for designing ergonomic products and work environment for the specially-abled and elderly is quite limited. This, otherwise, is more important as their real-life participation in experiments pertaining to the ergonomic evaluation of any product, workplace or public facility may cause discomfort to them. Moreover, improved products or workplace reduces their dependence on others and enables active involvement in work, communication, and social life. Therefore, an attempt has been made in this paper to explore the state of the art literature review on the applications of DHM based virtual ergonomic approaches to improve products and workplaces designs for specially-abled/elderly. The paper also proposes a way forward to continue research and developmental activities towards the betterment of the quality of life of the elderly and specially-abled persons through proactive and inclusive design strategies.
\end{abstract}

Keywords Digital human modeling (DHM) · Ergonomic design $\cdot$ Specially-abled $\cdot$ Elderly

\section{Introduction}

The ergonomic design of the work environment reduces postural stress, improves organizational productivity, enhances job satisfaction, and results in a better quality of work-life [1, 2]. With the advent of virtual ergonomics, user-centered workplaces and/or products are being developed and tested in a virtual environment at an early design phase. Human modeling software enables designers to simulate human -workplace interaction by inserting a digital human model in the CAD generated work environment. CAD-based virtual ergonomics evaluation process shortens design time, lowers development cost, improves quality and enhances productivity [3].

\subsection{Digital human modeling (DHM) software}

Digital human modeling software is a computer-aided design tool for the construction of $2 \mathrm{D}$ and $3 \mathrm{D}$ human models from anthropometric data of targeted users/population for ergonomic analysis of virtual human fit to virtual workstation components [4]. Any design or work environment can be evaluated from an ergonomics perspective using virtual simulation before making the real physical prototype [5]. The study of digital prototypes in virtual environment reduces the developmental cost and design time [6]. The correlation between the results of DHM simulation and real-life assessment is fairly high [7]. A few popular DHM software, which is commercially available include JACK, SAMMIE, RAMSIS, DELMIA, SANTOS, etc.

Charu M. Maurya, mauryacm@iitg.ac.in | 'Department of Design, Indian Institute of Technology, Guwahati, Assam, India. 


\subsection{Application of DHM software for improving the work environment}

Digital human modeling software has gained attention for proactive design and ergonomic evaluation of products and workplaces in diverse fields that include manufacturing industry, healthcare sectors, transportation, agriculture, defense research and development, aerospace-aviation sectors and so on. In industrial workplace, DHM has been applied for improving the designs of work cells in car manufacturing plants [8], designing of small fishing vessels to reduce work-related musculoskeletal disorders of fisherman [9], redesigning of work accessories for minimizing awkward postures in Indian shop floor workstation [10], workplace evaluation of coir industry, etc. [11].

The ergonomic analysis of refrigerated cabinets [12], shoe rack [13], adjustable walking cane [14], modified cycle rickshaw [15], improved load carrier for coolie [16] improved design of wearable load assisting device [17] etc. are few examples where DHM has been applied effectively. In the healthcare sector, DHM has been successfully utilized for improving laparoscopic surgery [18], evaluation of bathing system design for patients [19], patient lifting devices for healthcare personnel [20], etc.

DHM also finds its application in the field of transportation, aviation, and aerospace viz. vision analysis of pilots in jet aircraft [21], evaluation of cockpit design [22], vehicle interior design [23], evaluation of seat belt, driver posture and comfort in vehicles $[24,25]$. Inclusion of DHM in the design process of the agricultural tools and machinery [26-28] is also gaining popularity.

\subsection{Need of DHM application for improving the work environment of the specially-abled and elderly}

Following the literature review, it is evident that a large number of research and developmental activities have been carried out by applying DHM in product and workplace design for military personnel, automobile drivers, healthcare professionals and for general civilian populations. Researches on DHM applications in the design and development of products for specific population subgroups like elderly and specially-abled persons have received less attention. Thus, there is a scope for needbased design of products and support systems for such specific sub-populations by taking the advantages of DHM technologies. A user-centric work environment or ergonomic products is an utmost necessity for the specially-abled or elderly as they encounter various barriers like inadequate policies and standards, negative attitude, lack of provision of services and the problem with service delivery, etc. [29]. Specially-abled employees who work in uncomfortable workplaces have also complained of mobility trouble, problems associated with heart and blood circulation, depression, etc. [30]. They also face difficulties while traveling and using public transport [31], which prevents their participation in social and work life [29]. Apart from that, specially-abled persons also encounter other disparities like lower average pay, job insecurity, lack of training facilities, participation in decision-making, etc. [32]. Hence, convenient housing and adequate support services should be provided to the specially-abled or elderly people [33]. Moreover, planners, designers, and architects should adopt universal and inclusive designs approach to remove obstacles in accommodation, transportation and communication to empower the specially-abled to participate independently and comfortably in education, employment and social life [29]. In the scenario described above, virtual prototyping with DHM could enable the designer to evaluate the product and modify it by simulating the interaction of digital manikin with the CAD model of the product [34]. Digital manikin-based virtual testing of the product-user interface also reduces discomforts/troubles to the elderly and specially-abled persons by eliminating their actual participation in real experiments of physical compatibility evaluation.

\section{Aim}

The aim of the current paper is to explore the state of the art literature review on applications of DHM based virtual ergonomic approaches in improving the product and workplaces designs for specially-abled/elderly. The paper also proposes a way forward to continue research and developmental activities towards the betterment of the quality of life of the elderly and specially-abled persons through proactive and inclusive design strategies.

\section{Results}

The papers published in peer-reviewed English journals and conference proceedings using DHM for a product or workplace analysis and having the specially-abled or elderly as participants were considered for the present review. The studies pertaining to anthropometric databases of elderly and specially-abled for making their digital manikin were identified from the available literature. Areas such as industries, public places, sports, product design, healthcare, etc. 
were also explored where DHM has been used for solving design related issues of specially-abled and elderly.

\subsection{Anthropometric database of the specially-abled and elderly for DHM}

Anthropometry is one of the important aspects of DHM based product/workplace design and evaluation. Different anthropometric databases are incorporated in DHM software to get the digital manikin for the targeted population in the simulation process [35]. Fourteen (14) studies dealing with the creation of anthropometric databases of elderly and specially-abled have been included in the present review. D'souza et al. [36] in their study created functional reach database of 320 users of wheel mobility devices using DMH software and applied it for calculating vertical reach ranges for forward and side-ways. A model to predict reach envelop of digital human model based on data collected from elderly subjects was also proposed [37]. Another human modeling software "HADRIAN" (human anthropometric data requirement investigation and analysis) was developed [38-43] where anthropometric data, range of motion data, reach range, data regarding the ability to do kitchen based activities in daily life were recorded from 102 respondents. The elderly having age-related impairments and specially-abled persons (covering a wide range of disability) were selected as respondents. The HADRIAN software was validated by comparing the results of HADRIAN manikins with the actual users while performing the task such as retrieving a ticket from the machine, using ATM to obtain cash or using the lift at the railway station [44]. Hogberg et al. [45] developed digital human models of the elderly by modifying the anthropometric and joint range of motion data. Anthropometric data of elderly and their caregiver was also collected [46] to develop $3 \mathrm{D}$ digital interactive works environment through which movements of caregivers of elderly can be studied and improved through training. Chaffin [47] recorded 37,000 motions from people in the age group of 18-78 years for developing a database of human motion prediction models. The motions of the people while reaching and moving the light to moderate objects in either seated or in standing postures were recorded. The models can help to predict various motor behavioral strategies adopted by a different group of people within a virtual workplace. Motion capture technology to create digital human models of specially-abled people was also applied $[48,49]$.

\subsection{DHM application for improving industrial workplace}

Earlier researchers have reported few studies where DHM has been applied for improving the workplace of specially-abled and elderly. Aubry et al. proposed an approach for the ergonomic analysis of the speciallyabled person's workplace. In this approach gesturebased description of the workplace, virtual environment and modeling of disability as motion constraints were utilized. Thus, motions of the specially-abled person affected by his/her disability were generated and ergonomic analysis of workplace (3D CAD model) was performed [50]. A discomfort model of the climbing task for a specially-abled worker with prosthesis limb was also developed. The model was validated by simulating ladder-climbing task with the model of digital under knee prosthesis wearer and the results were compared with statistical data from the observed experiment [51]. Kaklanis et al. introduced a new virtual modeling technique comprising virtual user models, task models, and simulation models as a core component of a simulation module, expressed in UsiXML format. Here, the virtual user model was described as a virtual user with disabilities, simulation model was described as the product/ services to be tested, and a task model was described as the complex tasks of the user. The effectiveness of the proposed framework was evaluated virtually by examining the accessibility of a workplace to five virtual user models with different disabilities [52]. In a study, a digital manikin of the wheelchair user was developed and interfaced with the simulated workplace environment. The work environment was evaluated and all modifications were incorporated virtually [53]. In another study, immersive virtual reality technology was used to assess the modified workplace where a person with disability accessed virtual reality environment. The specific behavior of physically handicapped was studied in a virtual environment by integrating task and physical disability constraints. Their model considered three levels of constraints namely appearance (broken arm or amputation), kinematics (inaccurate pointing or less degree of freedom of joints) and physical (strength limits) that affect the motion and posture of physically handicapped in task performance [54]. An office environment for the elderly and disabled was evaluated using DHM software in a simulated environment and in a real scenario with actual users. Both evaluations gave similar results regarding accessibility features in office design [55]. Digital human modeling based inclusive design strategy was adopted in a study for evaluating furniture manufacturing assembly for an elderly worker having joint mobility constraints. A human model based on joint mobility data of elderly worker from HADRIAN database was developed. The posture adopted by workers in the furniture assembly environment was replicated virtually on a human model of the elderly worker to assess the acceptability of posture [56]. 


\subsection{DHM application for public utilities}

A few reported studies have illustrated the use of DHM for making public utilities comfortably accessible to the specially-abled. Li et al. examined the interaction behavior of wheelchair users with ATM machine in a virtual environment using DHM and immersive virtual reality technique. Comfort analysis of digital manikin was performed in DHM software. EMG measures of a person while using ATM with immersive virtual reality technique were also recorded. Both the results were compared with the subjective responses of real respondents [57]. In another study, the design of the ATM machine was also virtually evaluated and modified by studying its interaction with the digital human model of a wheelchair user from HADRIAN database [43].

A pedestrian simulation model to make the barrierfree environment for elderly and specially-abled at public buildings is being developed [58]. Such a simulation model at public places will be able to evaluate the visibility of the guidance system and reveal the areas not visible to the specially-abled [59].

\subsection{DHM application in healthcare sectors}

Healthcare sector is also taking benefit of DHM technology for designing prosthesis, exoskeleton and assistive aids. Morotti et al., Colombo et al. and Colombo et al. created two digital human models for transtibial amputee and transfemoral amputee. Its gait was simulated for analyzing causes of gait deviations related to prosthesis set up and socket modeling [60-62] (Fig. 1). A system for designing sockets for lower limb prosthesis was also developed. This system designs sockets based on the patient's weight, lifestyle, tonicity level and geometry of residuum [63]. A virtual prototype of intelligent bionic leg (IBL), an advanced trans-femoral prosthesis, was developed and virtually evaluated by Xie et al. [64].

For designing exoskeletons, musculoskeletal analysis of upper limb exoskeleton in a simulated environment was performed [65]. In this way, the designs of the exoskeleton can biomechanically be evaluated before making an actual prototype. To analyze the effect of the strap that connects the exoskeleton with the human body, a combined human exoskeleton model was developed and evaluated in a simulated environment [66]. Virtual prototyping of rehabilitation exoskeleton by merging computational musculoskeletal analysis with simulation was also proposed [67]. In the proposed framework an exoskeleton-limb musculoskeletal model is developed first and then its performance is assessed using biomechanical, morphological and controller parameters. These parameters are optimized for developing the virtual design. The virtual experiment is then carried out to generate a modification in the design if required. The application of such a framework was illustrated by developing the index finger exoskeleton prototype.

In the area of assistive aids, a modified DHM tool was applied for ergonomic evaluation of a bathing system design from caretakers' (elderly) and caregivers' point of view. Most suitable bathing posture was also defined. Anthropometrics, joint range of motion, description, and appearance were customized for developing manikins of the elderly. RULA and joint comfort values were used to evaluate bathing system design [19]. A walker with sitstand assistance for the elderly was developed and virtually evaluated on the human model before experimenting on real users [68]. A sit to stand and mobility assistance

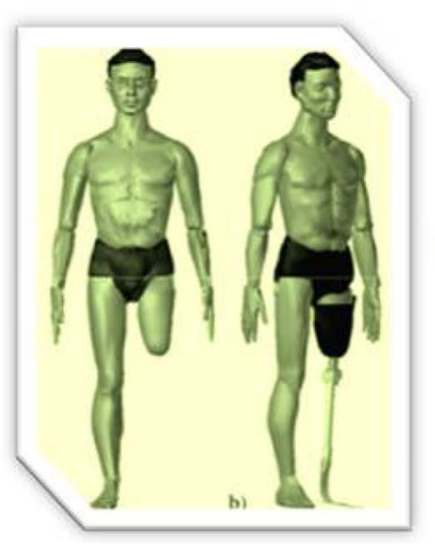

(a)

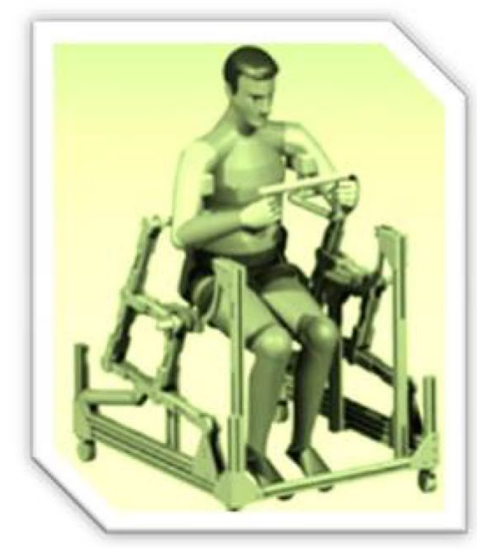

(b)

Fig. 1 DHM application in a prosthesis design from Colombo et al. [62] and $\mathbf{b}$ assistive aids for elderly and specially-abled from Khan et al. [69] 
device for the elderly was also developed and virtually evaluated by Khan et al. [69]. Out of numerous case examples, two prominent usages of DHM in the design of prosthesis for the person with amputated leg and assistive aids for the elderly and specially-abled have been depicted in Fig. 1 for the easy understanding of the readers.

Application of virtual human for assisted healthcare is also evolving. The virtual human with characteristics like speech recognition, natural vision, and language allows a human user to interact with their computer in a more natural way. The virtual human monitor the type of user such as old age person or disable, record data from sensors and communicate the data to healthcare professionals. Currently, virtual patient technology has been applied for mental health diagnosis and clinical training [70]. Kakijaki et al. applied digital human modeling to physiotherapy education for 3D visualization and analysis of gait motion of the normal and hemiplegic patient [71].

\subsection{DHM application in sports}

DHM was applied by Holmberg et al. for understanding the effect of the impairment on sport's performance [72]. In their study musculoskeletal simulation for skiing sport was carried out on digital manikin with lower leg prosthesis. The influence of technique, fitness, and training was taken as negligible. Two full-body simulation models with identical anthropometric data were created having similar kinematics and external kinetics. In order to assess the impact of prosthesis on muscular work, one model was composed of full muscle setup and the other without muscle setup in right lower leg and foot. Biomechanical simulation of cross-country skiing was performed on both manikins. The output was used for computing metabolic muscle work and skiing efficiency. The results indicated that without muscles in leg and foot, skiing demanded more muscular efforts in total.

\subsection{DHM for vehicle design and assessment}

DHM has also gained the attention of researchers for designing and analyzing vehicles, which can be comfortable to specially-abled and elderly. A humanoid model was used for analyzing techniques adopted by the elderly in getting into a car [73]. Vehicle egress strategies and constraints faced by the elderly were also evaluated using RAMSIS bodybuilder [74]. A virtual modeling technique was used for evaluating car designs for hand brake and storage compartment use with a virtual model of the elderly having spinal cord injury by Kaklanis et al. [75]. Erdelyi et al. virtually evaluated the vibrational comfort level of the motorcycle ride with human models of able-bodied riders and people with different disabilities using root mean square (RMS) and vibration dose value (VDV) [76]. The suitability of a bus design for elderly and disabled people was also analyzed by Marshall et al. using digital manikin of specially-abled and elderly from HADRIAN database [77]. To provide the glimpse of application of DHM software in vehicle design and evaluation targeting for elderly and specially-abled people as the users, current researchers have compiled images from various pieces of literature and presented in Fig. 2.

\subsection{DHM application in other areas}

A model for simulating motion according to age by incorporating age-related changes in gait pattern, kinematics, and kinetic values has also been developed [78]. The model can be used for analyzing crowd behavior in the virtual environment. Wyk [79] worked on a methodology which can help to set up an open framework where a virtual human can be animated for visualizing sign language. In this method, any verbal language can be translated into a sign language in a machine translation system.

\section{Future work}

The participation of specially-abled or elderly in the reallife design development and evaluation process might cause discomfort to them. However, ergonomic design that suits their needs is very much required for minimizing the effects of constraints caused by their disability. The review presents the holistic knowledge base regarding the applications of DHM technology by various researchers in improving the quality of life of the elderly and specially-abled people. It is hoped that it would encourage researchers to develop and modify designs of products of everyday use for the aforesaid targeted users. DHM based virtual ergonomics evaluations in the field of transport, public utilities like hospital environment, markets, parks, temples, etc. are needed for modifying existing design towards more inclusive considering the specific requirements of the elderly and specially-abled persons as these public places are frequently accessed by them. In the living environment, designs of the bathroom, toilets, furniture, etc. can also be evaluated and accordingly design modifications can be performed to address ergonomic issues if any. DHM can also be applied to design and evaluate assistive aids and prosthesis to make them more user-friendly.

\section{Discussion and conclusion}

The present paper explores the areas where DHM has been applied for ergonomic evaluations and improving the work environment of elderly and specially-abled persons. The paper highlights the efforts done by researchers for 


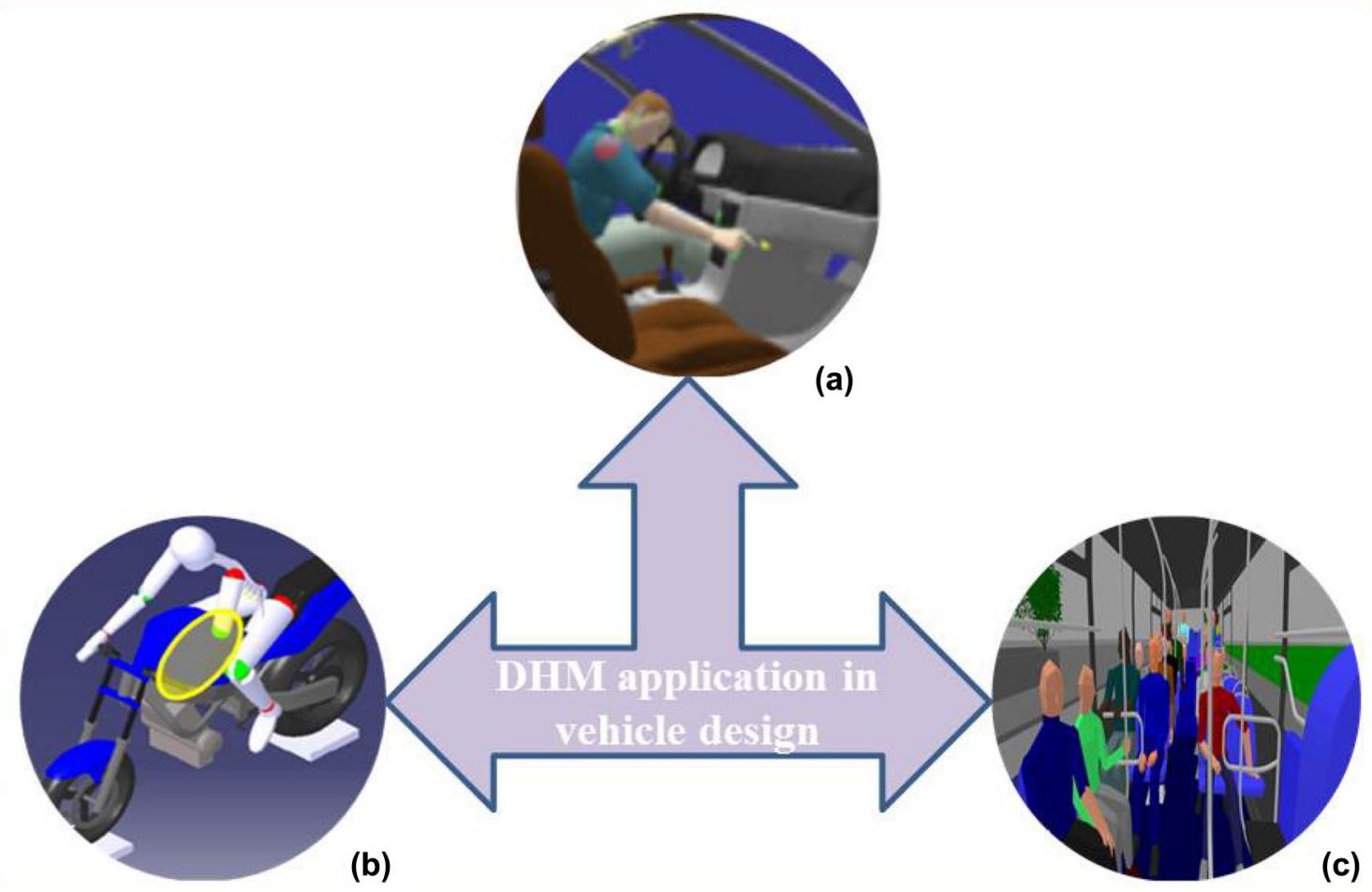

Fig. 2 DHM application in vehicle design and evaluation for elderly and specially-abled. Images adopted from a Kaklanis et al. [75], b Erdelyi et al. [76] and c Marshall et al. [77]

recording anthropometric and biomechanical data of specially-abled and elderly people and developing software such as HADRIAN. DHM has been applied for evaluating and modifying the workplaces viz. industrial workplace, public utilities, vehicle design, prosthesis design, etc. to make it compatible with elderly and specially-abled. Specially-abled employees often encounter problems viz. trouble in mobility, blood circulation, and depression in the industrial workplace. DHM can be of immense help in solving the workplace-related problems of the speciallyabled as done in case of office design [55] and furniture assembly [56]. Physical disability often hampers the movement of specially-abled and elderly and absence of appropriate physical infrastructures discourages their interaction in the social environment. DHM can be effectively used for virtual evaluation and improvement of the infrastructural facility of public places like ATM, railway station, bus-stop and public transportations. The current paper also highlights the research and development activities carried out by the researchers for designing assistive aids, prosthesis, and exoskeleton with the help of DHM and its successful evaluation in a simulated environment. In the automotive industry, suitable modifications in the design of hand brake, storage compartment has been undertaken using DHM in order to make it comfortable for speciallyabled and elderly.

\section{SN Applied Sciences}

Though limited, DHM has now been applied by researchers in the design process for making the work environment suitable for the specially-abled and elderly people. The major bottleneck for application of digital human modeling for product and facility design for elderly and specially-abled is the unavailability of anthropometric and biomechanical (total range of motion and comfort range of motion of body joints) databases of the aforesaid populations. This is true for most of the countries all over the world. Hence, the need of the hour is to develop such databases for effective use of DHM software to provide a better quality of life to these targeted users. It is envisaged that the body of literature presented in the current review would encourage designers and engineers to use DHM based ergonomic evaluation as an inclusive design approach for ensuring a barrier-free environment for the specially-abled and the elderly persons. The future research pertaining to applications of DHM software in developing manikins (with anthropometric and biomechanical data of elderly and specially-abled population) for ergonomic design and development of various products and facilities as described in current review would facilitate the quality of life of the elderly and specially-abled persons. 


\section{Compliance with ethical standards}

Conflict of interest On behalf of all authors, the corresponding author states that there is no conflict of interest.

\section{References}

1. Afroz S, Haque MI (2017) Ergonomics in the workplace for a better quality of work life. In: Muzammil M, Khan AA, Farooq M, Hassan $F$ (eds). In: Proceedings of 15th international conference on Ergonomics for improved productivity (HWWE 2017). Excel Publishers, New Delhi, p 70

2. Easwaran N (2017) Ergonomic analysis and workplace evaluation of an assembly section to improve productivity. In: Muzammil M, Khan AA, Farooq M, Hassan F (eds) Proceedings of 15th international conference on ergonomics for improved productivity (HWWE 2017). Excel Publishers, New Delhi, p 19

3. Naumann A, Roetting M (2007) Digital human modeling for design and evaluation of human machine systems. MMI Interaktiv 1:27-35

4. Chaffin DB (2005) Improving digital human modeling for proactive ergonomics in design. Ergonomics 48:478-491

5. Cappelli TM, Duffy VG (2006) Motion capture for job risk classifications incorporating dynamic aspects of work. In: Digital human modeling for design and engineering conference, Lyon, 4-6 July 2006. SAE International, Warrendale

6. Zhang X, Chaffin DB (2005) Digital human modeling for computer-aided ergonomics. Handbook of occupational ergonomics. CRC Press, London, pp 1-13

7. Fritzsche $L$ (2010) Ergonomics risk assessment with digital human models in car assembly: simulation versus real life. Hum Fact Ergon Manuf 20:287-299. https://doi.org/10.1002/ hfm. 20221

8. Spada S, Germana D, Ghibaudo L, Sessa F (2013) Application and benefits of digital human models to improve the design of work cells in car's manufacturing plants according to international standards. Proceedings of the 11 th international conference on manufacturing research (ICMR 2013). http://dspace.lib.cranfield. ac.uk/handle/1826/9490. Accessed 12 May 2017

9. Álvarez-Casado E, Zhang B, Sandoval ST, Pedro M (2016) Using ergonomic digital human modeling in evaluation of workplace design and prevention of work-related musculoskeletal disorders aboard small fishing vessels. Hum Fact Ergon Manuf 26:463-472. https://doi.org/10.1002/hfm.20321

10. Sanjog J, Baruah RL, Patel T, Karmakar S (2016) Redesign of work-accessories towards minimizing awkward posture and reduction of work cycle elements in an Indian shop-floor workstation. In: Rebelo F, Soares M (eds) Advances in ergonomics in design. Advances in intelligent systems and computing, vol 485 . Springer, Cham

11. Satheeshkumar M, Krishnakumar K (2016) Ergonomic analysis of workstations in coir mat industries in Kerala using digital human modeling method. In: Bhardwaj A, Singh LP, Singh S (eds) Proceedings of 14th international conference on humanizing work and work environment (HWWE 2016), GIAP journals, pp 87-89

12. Colombo G, Ponti DG, Rizzi C (2009) Digital human modeling for ergonomic analysis of refrigerated cabinets. https://www.desig nsociety.org/publication/32297/digital_human_modeling_for_ ergonomic_analysis_of_refrigerated_cabinets. Accessed $12 \mathrm{Mar}$ 2018

13. Sanjog J, Karmakar S, Agarwal H, Patil CD (2012) Designing and ergonomic evaluation of a shoe-rack in CAD environment. Int $J$ Comput Appl 49:38-41
14. Sahoo BB, Yein N, Pal S (2015) Design concept of adjustable cane-chair for elderly in virtual environment. In: Proceedings of 13th international conference on humanizing work and work environment 2015 \& community nutrition and health: a social responsibility. Patel Digital Printers, Mumbai, p 46

15. Mohapatra S (2015) Application of digital human modeling and work posture analysis of human powered cycle rickshaw pullers on Odisha, India-a case study. In: Proceedings of 13th international conference on humanizing work and work environment 2015 \& community nutrition and health: a social responsibility. Patel Digital Printers, Mumbai, p 228

16. Shroff A, Mohapatra S (2015) Computer-aided ergonomics: design, development and ergonomic analysis of load carrier for an Indian coolie. In: Proceedings of 13th international conference on humanizing work and work environment 2015 \& community nutrition and health: a social responsibility. Patel Digital Printers, Mumbai, p 258

17. Sharma HK, Sharma AK, Singh A, Singhal P (2017) Digital human modeling using catia-V5 for the analysis and ergonomic improvements in the design of wearable load assisting device for porters. In: Muzammil M, Khan AA, Farooq M, Hassan F (eds) Proceedings of 15th international conference on ergonomics for improved productivity (HWWE 2017). Excel Publishers, New Delhi, p 31

18. Marcos P, Seitz T, Bubb H, Wichert A, Feussner H (2006) Computer simulation for ergonomic improvements in laparoscopic surgery. Appl Ergon 37:251-258. https://doi.org/10.1016/j.aperg 0.2005 .09 .003

19. Hanson L, Hogberg D, Lundstrom D, Warell M (2009) Application of human modeling in healthcare industries. In: Duffy VG (ed) Digital human modeling. ICDHM 2009, LNCS 5620. Springer, NewYork. https://doi.org/10.1007/978-3-642-02809-0_55

20. Cao W, Jiang M, Han Y, Khasawneh MT (2013) Ergonomic assessment of patient barrow lifting technique using digital human modelling. In: Duffy VG (ed) Digital human modeling and applications in health, safety, ergonomics, and risk management, human body modeling and ergonomics. DHM 2013, LNCS 8026. Springer, Berlin. https://doi.org/10.1007/978-3-642-39182-8_3

21. Karmakar S, Pal MS, Majumdar DA, Majumdar DB (2012) Application of digital human modeling and simulation for vision analysis of pilots in a jet air craft: a case study. Work 41:3412-3418. https://doi.org/10.3233/WOR-2012-0617-3412

22. Xue H, Zhang X, Chen Y, Zhou L (2014) Comfort evaluation of cockpit based on dynamic pilot posture. In: Duffy VG (ed) Digital human modeling. Applications in health, safety, ergonomics and risk management. DHM 2014, LNCS 8529. Springer, New York, pp 215-223. https://doi.org/10.1007/978-3-319-07725 -3_15

23. Yang J, Kim JH, Abdel-Malek K, Marler T, Beck S, Kopp GR (2007) A new digital human environment and assessment of vehicle interior design. Comput Aided Des 39:548-558. https://doi. org/10.1016/j.cad.2006.11.007

24. Meulen PVD, Seidl A (2007) Ramsis-the leading CAD tool for ergonomic analysis of vehicles. In: Duffy VG (ed) Digital human modeling. ICDHM 2007, LNCS 4561. Springer, New York, pp 215-223. https://doi.org/10.1007/978-3-540-73321-8_113

25. Kyung G, Nussabaum MA (2009) Specifying comfortable driving postures for ergonomic design and evaluation of the driver workspace using digital human models. Ergonomics 52:939953. https://doi.org/10.1080/00140130902763552

26. Fathallah FA, Chang J, Pickett W, Marlenga B (2009) Ability of youth operators to reach farm tractor controls. Ergonomics 52:685-694. https://doi.org/10.1080/00140130802524641

27. Wu GJ, Lin JJ, Chiu YC (2012) Computer aided human factor engineering analysis of a versatile agricultural power. In: Proceedings of the 6 th international symposium on machinery 
and mechatronics for agriculture and biosystems engineering (ISMAB). https://www.scientific.net/AEF.10.16.pdf. Accessed 21 June 2017

28. Dooley WK (2012) Ergonomics and the development of agricultural vehicles. American Society of Agricultural and Biological Engineers (ASABE) distinguished lecture series no. 36. https:// elibrary.asabe.org/data/pdf/6/edav2012/Lec_Series_2012.pdf. Accessed 18 Oct 2017

29. World Health Organization (2011) World report on disability. http://apps.who.int/iris/bitstream/10665/70670/1/WHO_NMH VIP_11.01_eng.pdf. Accessed 14 May 2017

30. Goldstone C (2002) Barriers to employment for disabled people. http://217.35.77.12/Cb/england/papers/pdfs/2002//H95. pdf. Accessed 25 Nov 2017

31. Soltani SHK, Sham M, Awang M, Yaman R (2012) Accessibility for disabled in public transport terminal. Proc Soc Behav Sci 35:89-96. https://doi.org/10.1016/j.sbspro.2012.02.066

32. Schur L, Kruse D, Blasi J, Blanck P (2009) Is disability disabling in all workplaces? Workplace disparities and corporate culture. Ind Relatsh 48:381-410. https://doi.org/10.1111/j.1468232X.2009.00565.X

33. Mgonela VA (2010) Obstacles and challenges faced by disabled women in employment opportunities in the public civil service in Tanzania: a case study of dar es salaam. Master's thesis, University of Zimbabwe

34. Krovi V, Kumar V, Ananthasuresh GK, Vezien JM (1999) Design and virtual prototyping of rehabilitation aids. J Mech Des 121. http://www.mecheng.iisc.ernet.in/ suresh/journal/J6Krovi119 99JMD.pdf. Accessed 25 Apr 2017

35. Satheeshkumar M, Krishnakumar K (2014) Digital human modeling approach in ergonomic design and evaluation-a review. Int J Sci Eng Res 5:617-623

36. D'Souza C, Steinfeld E, Paquet V (2009) Functional reach for wheeled mobility device users: a comparison with ADA-ABA guidelines for accessibility. https://www.resna.org/sites/defau It/files/legacy/conference/proceedings/2009/JEA/Student\%20 Papers/DSouza.html. Accessed 12 Sept 2017

37. Wang X, Chateauroux E, Chevalot N (2007) A data based modeling approach of reach capacity and discomfort for digital human models. In: Duffy VG (ed) Digital human modeling. ICDHM 2007, LNCS 4561. Springer, New York, pp 215-223. https ://doi.org/10.1007/978-3-540-73321-8_26

38. Gyi DE, Sims RE, Porter JM, Marshall R, Case K (2004) Representing older and disabled people in virtual user trials: data collection methods. Appl Ergon 35:443-451. https://doi.org/10.1016/j. apergo.2004.04.002

39. Porter JM, Case K, Marshall R, Gyi D, Nee Oliver RS (2004) Beyond Jack and Jill: designing for individuals using HADRIAN. Int J Ind Ergonom 33:249-264. https://doi.org/10.1016/j.ergon .2003.08.002

40. Marshall R, Summerskill S, Porter M, Case K, Sims R, Gyi D, Davis $P$ (2008) Multivariate design inclusion using HADRIAN. In: Digital human modeling for design and engineering conference and exhibition. http://www.sae.org/technical/papers/2008-01-1899. Accessed 10 Sept 2017

41. Case K, Marshall R, Hogberg D, Summerskill S, Gyi D, Sims R (2009) HADRIAN: fitting trials by digital human modelling. https ://link.springer.com/chapter/10.1007/978-3-642-02809-0_71. Accessed 25 July 2017

42. Marshall R, Gyi D, Case K, Porter JM, Sims RE, Summerskill SJ, Davis P (2009) A design ergonomic approach to accessibility and user needs in transport. In: Bust PD (ed) Contemporary ergonomics 2009: proceedings of the international conference on contemporary ergonomics 2009. https://pdfs.semanticsc holar.org/89fe/c972ffdf903d10f8ad40ace8581e6cf231e0.pdf. Accessed 2 July 2017
43. Marshall R, Case $K$, Porter M, Summerskill S, Gyi D, Davis P, Sims R (2010) HADRIAN: a virtual approach to design for all. J Eng Des 21:253-273. https://doi.org/10.1080/09544820903317019

44. Summerskill SJ, Marshall R, Gyi DE, Porter JM, Case K, Sims RE, Davis $P$ (2010) Validation of the HADRIAN system with a train station design case study. Int J Hum Fact Model Simul 1:420 432. https://doi.org/10.1504/IJHFMS.2010.040275

45. Hogberg D, Hanson L, Lundstrom D, Jonsson M, Lamskull D (2008) Representing the elderly in digital human modelling. www.arbetsliv.eu/nes2008/papers/1791.doc

46. Guimaraes C, Balbio V, Cid G, Zamberlane MC, Pastura F, Paixao L (2015) 3 D virtual environment system applied to aging studybiomechanical and anthropometric approach. Proc Manuf 3:5551-5556. https://doi.org/10.1016/j.promfg.2015.07.728

47. Chaffin DB (2002) On simulating human reach motions for ergonomic analyses. Hum Fact Ergon Manuf 12:235-247. https://doi. org/10.1002/hfm.10018

48. Jenkins GR (2005) The visualization of human function for use in environmental and product design. In: Proceedings of the RESNA 28th annual conference. https://www.resna.org/sites/ default/files/legacy/conference/proceedings/2005/Index.html. Accessed 14 May 2017

49. Jenikins G, Mahdjoubi L (2005) The development of computer visualizations of older people and disabled people to inform and instruct the design of the products and living spaces. In: 5th International postgraduate conference in the built and human environment. http://www.irbnet.de/daten/iconda/CIB16704. pdf. Accessed 10 Nov 2017

50. Aubry M, Julliard F, Gibet S (2009) Interactive ergonomic analysis of a physically disabled person's workplace. https://hal.archivesouvertes.fr/hal-00503246/document. Accessed 25 Nov 2017

51. Fu Y, Li S, Yin M, Bian Y (2009) Simulation-based discomfort prediction of the lower limb handicapped with prosthesis in the climbing tasks. In: Duffy VG (ed) Digital human modeling, HCII 2009, LNCS 5620, pp 521-527. https://link.springer.com/chapt er/10.1007/978-3-642-02809-0_54 Accessed 12 Sept 2017

52. Kaklanis N, Moschonas P, Moustakas K, Tzovaras D (2010) Enforcing accessible design of products and services through simulated accessibility evaluation. In: González K, Kalla V (eds) Tangible information technology for a better ageing society, confidence, pp 59-71. http://www.iti.gr/ moustak/Confidence 10_SimulatedAccessbility.pdf. Accessed 10 Sept 2017

53. Budziszewski P, Grabowski A, Milanowicz M, Jankowski J, Dzwiarek M (2011) Designing a workplace for workers with motion disability with computer simulation and virtual reality techniques. Int J Disabil Hum Dev. https://doi.org/10.1515/ IJDHD.2011.054

54. Yan FU, Shiqi L, Gwen-guo C (2013) Motion/posture modeling and simulation verification of physically handicapped in manufacturing system design. Chin J Mech Eng. https://doi. org/10.3901/CJME.2013

55. Moschonas P, Paliokas I, Tzovaras D (2014) A novel accessibility assessment framework for the elderly: evaluation in a case study on office design. In: Proceedings of 8th international conference of pervasive computing technologies for healthcare. https://doi. org/10.4108/icst.pervasivehealth.2014.255349

56. Case K, Hussain A, Marshall R, Summerskill S, Gyi D (2015) Digital human modeling and the computer-aided workforce. Proc Manuf 3:3694-3701. https://doi.org/10.1016/j.promf g.2015.07.794

57. Li K, Duffy VG, Zheng L (2006) Universal accessibility assessments through virtual interactive design. Int J Hum Fact Model Simul 1:52-68. https://doi.org/10.1504/JHFMS.2006.01168

58. Brunnhuber M, Schrom-Feiertag H, Hesina G, Bauer D, Purgathofer W (2010) Simulation and visualization of the behaviour of handicapped people in virtually reconstructed public buildings. 
https://www.researchgate.net/publication/228677311_Simul ation_and_Visualization_of_the_Behavior_of_Handicappe d_People_in_Virtually_Reconstructed_Public_Buildings

59. Schrom-Feiertag H, Matyus T, Brunnhuber M (2011) Simulation of handicapped people finding their way through transport infrastructures. In: Weidmann U, Kirsch U, Schreckenberg M (eds) Pedestrian and evacuation dynamics. https://link.springer.com/ chapter/10.1007/978-3-319-02447-9_78. Accessed 10 Sept 2017

60. Morotti R, Rizzi C, Regazzoni D, Colombo G (2007) Digital human modeling to analyse virtual amputee's interaction with prosthesis. In: Proceedings of the ASME 2014 international design engineering technical conferences and computers and information in engineering conference IDETC/CIE. https://doi.org/10.1115/ DETC2014-34381

61. Colombo G, Facoetti G, Rizzi C (2013) A digital patient for computer aided prosthesis design. Interface Focus 8:8-9. https://doi. org/10.1098/rsfs.2012.0082

62. Colombo G, Facoetti G, Regazzoni D, Rizzi C (2015) Virtual patient to assess prosthetic devices. https://www.semanticsc holar.org/paper/G-Colombo-Virtual-Patient-Virtual-Patient-toAsses-Colombo-Facoetti/1 efb8ad86338a6b6f5aaded369c301 207bf7ff63. Accessed 13 Nov 2017

63. Colombo G, Facoetti G, Rizzi C (2016) Automatic below-knee prosthesis socket design: a preliminary approach. https://link. springer.com/chapter/10.1007/978-3-319-40247-5_8\#citeas. Accessed 12 Sept 2017

64. Xie H, Kang G, Li F (2013) The design and control simulation of trans-femoral prosthesis based on virtual prototype. Int J Hybrid Inf Technol 6:91-100. https://doi.org/10.14257/ijhit.2013.6.6.08

65. Agarwal P, Narayan MS, Lee LF, Mendal F, Krovi V (2010) Simulation- based design of exoskeletons using musculoskeletal analysis. In: Proceedings of ASME 2010 international design engineering technical conference. https://doi.org/https://doi. org/10.1115/detc2010-28572

66. Cho K, Kim Y, Yi D, Jung M, Lee K (2012) Analysis and evaluation of a combined human-exoskeleton model under two different constraints condition. In: Proceedings of the international summit on human simulation. https://www.researchgate.net/ publication/263505202_Analysis_and_evaluation_of_a_combi ned_human_-_exoskeleton_model_under_two_different_const raints_condition. Accessed 16 Nov 2017

67. Agarwal P, Kuo PH, Neptune RR, Deshpande AD (2013) A novel framework for virtual prototyping of Rehabilitation exoskeletons. https://www.ncbi.nlm.nih.gov/pubmed/24187201. Accessed 13 Nov 2017

68. Chugo D, Takase K (2009) A rehabilitation walker with a standing assistance device. https://www.intechopen.com/books/rehab ilitation-engineering/a-rehabilitation-walker-with-a-standingassistance-device. Accessed 25 Nov 2018

69. Khan MR, Patnaik B, Patel S (2017) Design and development of a novel sit-to-stand and mobility assistive device for ambulation and elderly. In: Chakrabarti D, Chakrabarti A (eds) Research into design for communities, vol 1, ICoRD'17. Smart innovation.
Systems and Technologies, New York, pp 801-811. https://doi. org/10.1007/978-981-10-3518-0_69

70. Kenny P, Parsons T, Gratch J, Rizzo A (2008) Virtual humans for assisted healthcare. In: PETRA'08 proceedings of the 1 st international conference on pervasive technologies related to assistive environment. https://pdfs.semanticscholar.org/eb4b/0953d a6c2d2beee250d950bea1aa80dc45e7.pdf. Accessed 8 May 2017

71. Kakizaki T, Urii J, Endo M (2016) Application of digital human models for physiotherapy training. In: Proceedings of ASME 2010 international design engineering technical conferences and computers and information in engineering conference IDETC/CIE 2016. https://doi.org/10.1115/detc2016-59455. Accessed 15 Mar 2018

72. Holmberg LJ, Ohlsson ML, Danvind J (2012) Musculoskeletal simulations: a complimentary tool for classification of athletes with physical impairments. Prosthet Orthot Int 36:396-397

73. Ait El Menceur MO, Pudlo P, Gorce P, Thevenon A, Lepoutre FX (2008) Alternative movement identification in the automobile ingress and egress for young and elderly population with or without prosthesis. Int J Ind Ergonom 38:1078-1087. https:// doi.org/10.1016/j.ergon.2008.02.019

74. Chateauroux $E$, Wang $X$ (2010) Car egress analysis of young and old drivers for motion simulation. Appl Ergon 42:169-177

75. Kaklanis N, Moschonas P, Moustakas K, Tzovaras D (2011) A framework for automatic simulated accessibility assessment in virtual environments. In: Duffy VG (ed) Digital human modeling, HCII 2011, LNCS 6777, pp 302-311. https://link.springer.com/ chapter/10.1007/978-3-642-21799-9_34. Accessed 14 May 2017

76. Erderlyi H, Kirchner M, Manzato S, Donders S (2012) Multibody simulation with a virtual dummy for motorcycle vibration comfort assessment. https://www.researchgate.net/publicatio n/235718888_Multibody_simulation_with_a_virtual_dummy _for_motorcycle_vibration_comfort_assessment. Accessed 25 Nov 2017

77. Marshall R, Summerskill S, Case K, Hussain A, Gyi D, Sims R, Morris A, Barnes J (2016) Supporting a design driven approach to social inclusion and accessibility in transport. Soc Incl 4:7-23. https://doi.org/10.17645/si.v4i3.521

78. Duy Le D, Boulic R, Thalmann D (2003) Integrating age attributes to virtual human locomotion. In: Proceedings of international archives of the photogrammetry, remote sensing and spatial information sciences. http://www.isprs.org/proceedings/XXXIV /5-W10/papers/le.pdf. Accessed 14 May 2017

79. Wyk DE (2008) Virtual human modeling and animation for realtime sign language visualization. Master's thesis, University of the Western Cape

Publisher's Note Springer Nature remains neutral with regard to jurisdictional claims in published maps and institutional affiliations. 